$1-1-1973$

\title{
Potassium fertilization studies of alfalfa in West Virginia in relation to yield and longevity of alfalfa stands (1955-1970)
}

Robert F. Keefer

Follow this and additional works at: https://researchrepository.wvu.edu/ wv_agricultural_and_forestry_experiment_station_bulletins

\section{Digital Commons Citation}

Keefer, Robert F., "Potassium fertilization studies of alfalfa in West Virginia in relation to yield and longevity of alfalfa stands (1955-1970)" (1973). West Virginia Agricultural and Forestry Experiment Station Bulletins. 621T.

https://researchrepository.wvu.edu/wv_agricultural_and_forestry_experiment_station_bulletins/708 @ WVU. It has been accepted for inclusion in West Virginia Agricultural and Forestry Experiment Station Bulletins by an authorized administrator of The Research Repository @ WVU. For more information, please contact ian.harmon@mail.wvu.edu. 


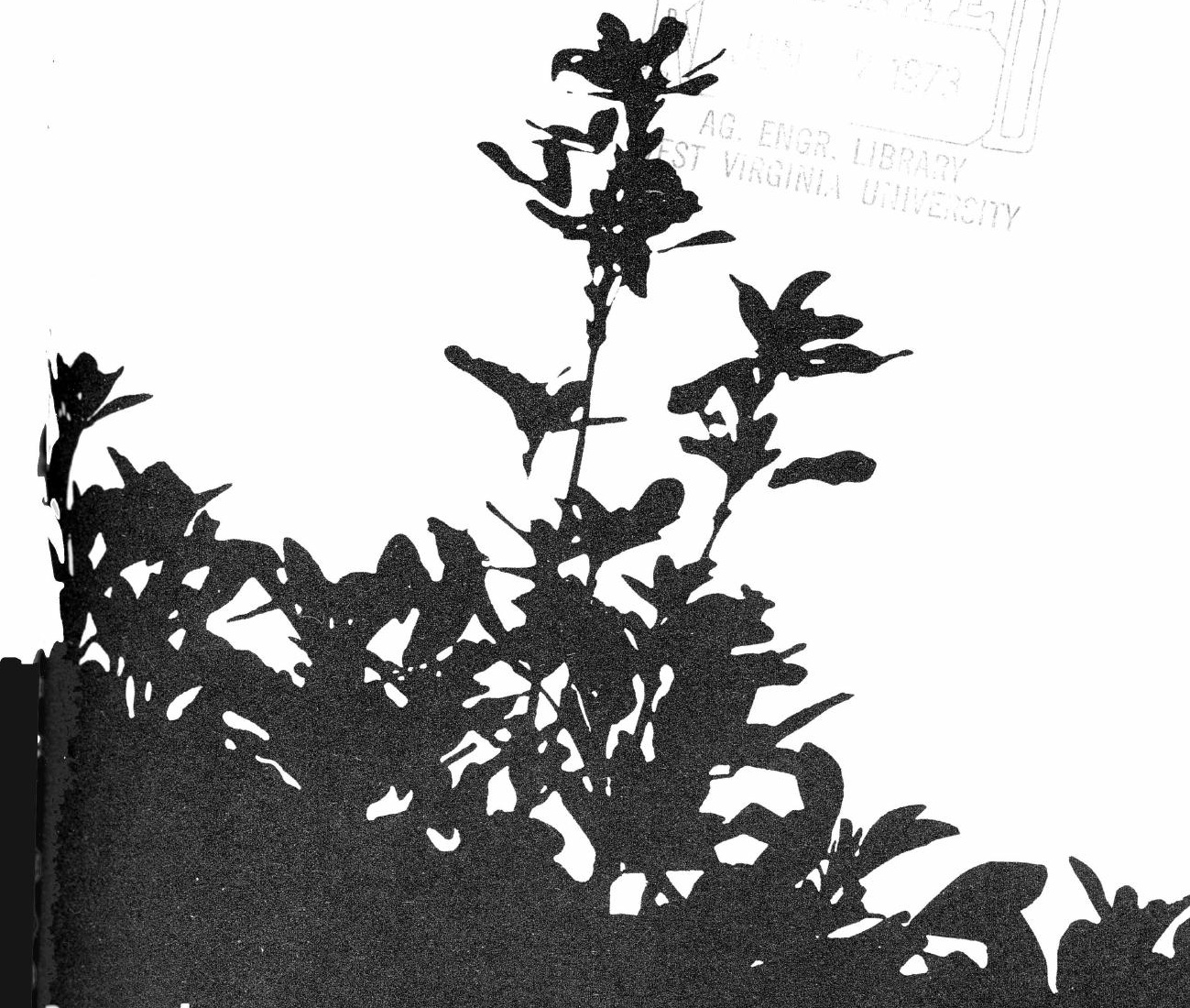

Potassium

Fertilization Studies of Alfalfa in West Virginia in Relation to Yield and Longevity of Alfalfa Stands (1955-1970)

Bulletin $621 \mathrm{r}$ April 1973 West Virginia University 


\title{
AUTHOR
}

R. F. Keefer is Associate Agronomist.

\section{ACKNOWLEDGMENTS}

The author wishes to express his appreciation to the many people who contributed their time and effort in the experimental part of this bulletin. Among those who devoted considerable time to this are G. A. Jung, G. G. Pohlman, F. J. Olsen, P. R. Henderlong, J. W. Hammer, W. P. Pinnell, L. P. Stevens, C. B. Sperow, and C. D. Reese.

\author{
WEST VIRGINIA UNIVERSITY \\ AGRICULTURAL EXPERIMENT STATION \\ COLLEGE OF AGRICULTURE AND FORESTRY \\ R. S. DUNBAR, JR., DIRECTOR \\ MORGANTOWN
}




\section{POTASSIUM FERTILIZATION STUDIES OF ALFALFA IN WEST VIRGINIA IN RELATION TO YIELD AND LONGEVITY OF ALFALFA STANDS (1955-1970)}

R. F. Keefer

Alfalfa has more advantages than any other forage. Among these are high yields of high protein forage when managed properly, drought and heat tolerance, long-lived stands either alone or in mixtures with grasses, ability to recover quickly after cutting, adaptability to a wide variety of climatic conditions, ease of establishing a stand, palatability, no summer dormancy, high in calcium concentration, and rich in vitamins, especially vitamins $A$ and $D$. In spite of the recent reduction in number of acres of alfalfa grown in West Virginia due to damage by the alfalfa weevil, this crop is still considered extremely important in livestock production. Control of the alfalfa weevil is under careful study and undoubtedly will be solved in a few years.

Several decades ago agronomists in West Virginia observed that the application of lime and phosphorus (P) fertilizer was the most important nutrient requirement for good stands and yields of alfalfa. Potassium (K) fertilization generally gave less response probably because yields were at lower levels than at the present and available soil $\mathrm{K}$ levels were at a high level. In this early work, fertilizer rates were considerably lower than those now used. Over a period of years, $\mathrm{K}$ reserves in soil were depleted. Recently, demonstration plots in West Virginia (1) showed that alfalfa yields harvested by farmers can be considerably increased by proper $\mathrm{K}$ fertilization. Total annual yield of alfalfa-grass on two farms was more than doubled, from 2 tons per acre (T/A) with no $K$ to 4.2 and 4.7 T/A when $\mathrm{K}$ was applied at $200 \mathrm{lb} \mathrm{K}$ O/A. This $\mathrm{K}$ increased the yield by increasing the amount of alfalfa in the crop from 20 per cent to 89 per cent.

Average yields of alfalfa often are lower than desired and stands do not last long. Factors entering into stand longevity include genetic makeup of the plant, climate, soil conditions, crop management and nutrient availability. Proper management and other facets related to this have been reported recently by Jung et al. (27) for West Virginia conditions.

Numerous experiments have shown that successful alfalfa production depends on adequate supplies of $\mathrm{K}$, either as available soil $\mathrm{K}$ or supplied as fertilizers. Alfalfa yields have been increased considerably at many locations $(1,2,8,11,16,17,20,24,30,37,43,47)$ by application of $K$. Soils differ in their ability to supply $K$ for adequate growth $(3,4,16,22)$; hence, different rates of $K$ have been reported as optimum for maximum production of alfalfa. 
Annual alfalfa yields of 4 to 6 T/A were maintained for as long as five years in Minnesota (39) by annual topdressing with 120-240 lb $\mathrm{K}_{2} \mathrm{O} / \mathrm{A}$; however, initial benefits of a single high $\mathrm{K}$ application of $240 \mathrm{lb} \mathrm{K} 2 \mathrm{O} / \mathrm{A}$ were gone by the third year. Marked alfalfa yield differences were also observed during the third year in Georgia (35) by application of $\mathrm{K}$ fertilizer at rates of $42 \mathrm{lb} \mathrm{K/A}$ for one variety and $167 \mathrm{lb} \mathrm{K/A}$ for another variety. Fertilized plots yielded an average of 4.5 T/A for the four-year period.

Alfalfa yields of 8-9 T/A/yr have been reported in the corn-belt $(15,23)$. These have been from large field operations on "good corn soil" but did require very high soil fertility levels and large applications of $K$ fertilizer of about $300 \mathrm{lb}$ $\mathrm{K}_{2} \mathrm{O} / \mathrm{A} / \mathrm{yr}$. Intensive management and high soil fertility were required, such as five cuttings per year and the use of high-yielding Flemish varieties. These yields cannot be maintained for many years as these varieties are susceptible to bacterial and Fusarium wilt. The variety Saranac is now used extensively in the Northeast as it yields well and resists wilt.

Alfalfa can successfully compete with grasses in a mixture only when adequate $K$ is provided (20). Blaser and Brady in New York (5) reported that when soil $\mathrm{K}$ was low, competition for, and hence uptake of, $\mathrm{K}$ was in the order: weeds $>$ grasses $>$ legumes. The cation exchange properties of the roots of these forage species have been used to explain this order of uptake (14). The absorptive ability of alfalfa for $K$ is much less than that of grasses, hence large amounts of available $\mathrm{K}$ must be provided in order to insure adequate $\mathrm{K}$ uptake by the alfalfa.

Experiments in Rhode Island (41) have shown that in a legume-grass mixture, reduction in annually applied $\mathrm{K}$ from 100 to $50 \mathrm{lb} \mathrm{K}_{2} \mathrm{O} / \mathrm{A}$ lowered the proportion of legumes four years after seeding from 50 per cent to 3 per cent and yield from 3.1 to $1.6 \mathrm{~T} / \mathrm{A}$.

Analyses of alfalfa topgrowth for $K$ have shown considerable variability from as low as 0.5 per cent $(4,43)$ to as high as 4.5 per cent $(22)$. When the percentage of $\mathrm{K}$ contained in the alfalfa crop was plotted against the logarithm of the number of pounds of exchangeable K/A in the soil on which the crop was grown, a linear relationship was observed (43). Likewise, data from Virginia (36) and Minnesota $(24,39)$ showed that $K$ content of alfalfa was affected by amount of $\mathrm{K}$ fertilizer applied.

Levels of $\mathrm{K}$ in the alfalfa crop necessary for optimum yield have been reported as 1.25 per cent $(11,43), 1.42$ to 1.84 per cent $(17), 1.8$ per cent $(9)$, 1.75 to 2.00 per cent (30), and 2.2 per cent (34). The critical level has increased with time and at present probably levels above 2 per cent are required for high yields.

Fertilization with $K$ has increased survival and persistence of alfalfa $(2,6,11,17,20,21,27,43,47,49)$. Minimum levels of $K$ in aerial alfalfa tissues for survival have been reported as 1.00 per cent (17), 0.9 to 1.1 per cent (47), 1.25 per cent (43), and 1.4 per cent (4). Jung and Smith (27) have shown that alfalfa plants have greater resistance to cold (freezing temperatures) when $K$ is applied at $200 \mathrm{lb} \mathrm{K} / \mathrm{A}$ and when $\mathrm{K}$ and $\mathrm{P}$ are kept at a 5:2 ratio than with lower rates of $K$ or different $K: P$ ratios. Potassium also has been found to be the most 
important element in increasing longevity and yield of alfalfa in Maine (9) and New Jersey (32). This has been ascribed to the importance of $K$ on the nutritional status of the alfalfa plant, particularly with respect to carbohydrate reserves (40).

Cutting management becomes less critical when alfalfa is adequately supplied with $\mathrm{K}(18,48)$; however, Smith in Wisconsin $(44)$ warns that maintaining high fertility will not compensate for poor management.

Only limited data are available on time of $\mathrm{K}$ fertilization for maximum benefit. No difference was found between spring and fall application in Minnesota (37). However, Kresge and Younts reported (30) that the best time for application of $\mathrm{K}$ in Maryland was a split application ( $1 / 2$ in spring and $1 / 2$ after first cutting), when compared to a single application, particularly when $83 \mathrm{lb}$ of $K / A$ was applied annually. When the $K$ rate was increased from $83 \mathrm{lb}$ to 165 or $331 \mathrm{lb} K / \mathrm{A}$, no significant differences were observed in total alfalfa yield in pure stands, but there were differences when alfalfa was combined with orchardgrass. Maximum yields of the legume-grass mixture were obtained when $\mathrm{K}$ application was split between spring and after first cutting, or all applied in early spring or all applied after the first cutting. Brown and Stafford in Maine (9) reported no noticeable difference in yield of alfalfa from three locations when $200 \mathrm{lb} \mathrm{K} / \mathrm{O} / \mathrm{A}$ was applied in a single annual topdressing in fall, or spring, or after the first cutting, or after the second cutting. They claimed the rate of $\mathrm{K}$ was more important than the time of application. No additional yield was obtained when $300 \mathrm{lb} \mathrm{K} \mathrm{K}_{2} \mathrm{O} / \mathrm{A}$ was applied in spring or as three split applications compared to $200 \mathrm{lb} \mathrm{K} \mathrm{K}_{2} \mathrm{O} / \mathrm{A}$ applied in early spring.

Data presented here will be a summary of $\mathrm{K}$ fertilization field experiments and demonstrations conducted with alfalfa in West Virginia from 1955 to 1970.

\section{EXPERIMENT I}

\section{Procedures}

Established stands of two varieties of alfalfa (Narragansett and Vernal) at the Agronomy Farm near Morgantown, W. Va., were divided into plots, and subjected to four $\mathrm{K}$ fertilization treatments, replicated four times, as follows:

\section{lb $\mathrm{K} \mathrm{O}$ added/A/yr}

\section{Treatment No.}

1

2

3

4
1955

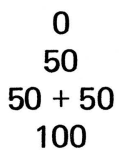

1956-1959

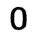

150

$150+150$

300

In treatment No. 3, the $\mathrm{K}$ was split between early spring and after first cutting. All plots were limed to $\mathrm{pH} 6.5$ and received $100 \mathrm{lb} \mathrm{P}_{2} \mathrm{O}_{5} / \mathrm{A}$ in 1955 and $200 \mathrm{lb}$ $\mathrm{P}_{2} \mathrm{O}_{5} / \mathrm{A}$ in 1956. The hay was harvested three times each year and total dry matter yield was calculated for each year. 
Persistence of alfalfa was measured by counting the number of alfalfa plants in 2 sq. ft. on each plot in spring and fall of 1956 and by estimating the per cent of alfalfa in the plots in 1958.

\section{RESULTS}

\section{Yield}

Hay yields (12 per cent moisture) usually increased as the amount of applied K/A increased (Table 1). The Narragansett variety yielded about $0.2 \mathrm{~T} / \mathrm{A}$ more than the Vernal variety over the five-year period; however, Vernal did yield better in the last year of the experiment indicating greater persistence. Application of more than $150 \mathrm{lb} \mathrm{K}_{2} \mathrm{O} / \mathrm{A}$ was usually not substantially beneficial.

\section{Persistence}

The number of alfalfa plants of both varieties in 1956 usually was related directly to the amount of $\mathrm{K}_{2} \mathrm{O} / \mathrm{A}$ applied (Table 2). More plants were found at the $300 \mathrm{lb} \mathrm{K}$ O/A level than at lower levels. No advantage was found for splitting the $K$ application. Narragansett variety averaged more plants per plot than Vernal in 1956; however, persistence of alfalfa as measured by visual estimate of percentage of alfalfa in the plots by 1958 was greater for the Vernal variety. The rate of $150 \mathrm{lb} \mathrm{K} \mathrm{K}_{2} \mathrm{O} / \mathrm{A}$ again was just as desirable as the higher $300 \mathrm{lb}$ A rate.

Table 1. Total yield of alfalfa hay for two varieties for five years in relation to amount of fertilizer $\mathrm{K}$ applied (Experiment $\mathrm{I}$ ).

\section{NARRAGANSETT}

Treatment*

\begin{tabular}{|c|c|c|c|c|c|c|}
\hline No. & Ib K $K_{2} \mathrm{O} / \mathrm{A} / \mathrm{yr}$ & 1955 & 1956 & 1957 & 1958 & 1959 \\
\hline 1 & 0 & $3.54^{* *}$ & 4.02 & 2.32 & 2.85 & 0.85 \\
\hline 2 & 150 & 3.56 & 4.65 & 3.56 & 4.01 & 2.02 \\
\hline 3 & $150+150$ & 3.52 & 4.31 & 3.56 & 3.87 & 2.31 \\
\hline 4 & 300 & 3.65 & 4.58 & 3.80 & 4.20 & 2.26 \\
\hline
\end{tabular}

Treatment*

\begin{tabular}{|c|c|c|c|c|c|c|c|}
\hline No. & Ib $K_{2} \mathrm{O} / \mathrm{A} / \mathrm{yr}$ & 1955 & 1956 & 1957 & 1958 & 1959 & mean \\
\hline 1 & 0 & 3.11 & 3.47 & 2.15 & 3.02 & 1.08 & 2.57 \\
\hline 2 & 150 & 3.00 & 3.91 & 3.13 & 3.96 & 2.36 & 3.27 \\
\hline 2 & $150+150$ & 3.22 & 3.98 & 3.56 & 3.99 & 2.80 & 3.51 \\
\hline 4 & 300 & 3.38 & 4.13 & 3.45 & 4.07 & 2.55 & 3.52 \\
\hline
\end{tabular}


Table 2. Persistence of alfalfa as measured by stand counts and per cent of alfalfa in plots in relation to amount of fertilizer $\mathrm{K}$ applied

(Experiment I).

NARRAGANSETT

Treatments*

Stand counts 1956

$\begin{array}{cccrcc}\text { No. } & \text { lb } \mathrm{K}_{\mathbf{2}} \mathrm{O} / \mathrm{A} / \mathrm{yr} . & \text { Spring } & \text { Fall } & \text { mean } & \begin{array}{c}\% \text { alfalfa in } \\ \text { plots-1958 }\end{array} \\ 1 & 0 & 9.8^{* *} & 8.5 & 9.2 & 33 \\ 2 & 150 & 11.8 & 8.8 & 10.3 & 52 \\ 3 & 150+150 & 10.8 & 11.0 & 10.9 & 43 \\ 4 & 300 & 11.5 & 10.8 & 11.2 & 51\end{array}$

\section{VERNAL}

Treatments*

Stand counts 1956

$\begin{array}{cccccr}\text { No. } & \text { lb } \mathrm{K}_{\mathbf{2}} \mathrm{O} / \mathrm{A} / \mathrm{yr} . & \text { Spring } & \text { Fall } & \text { mean } & \text { plots-195 } \\ 1 & 0 & 7.2 & 6.2 & 6.7 & 53 \\ 2 & 150 & 8.5 & 9.0 & 8.8 & 74 \\ 3 & 150+150 & 9.2 & 9.5 & 9.4 & 65 \\ 4 & 300 & 10.5 & 9.5 & 10.0 & 71\end{array}$

*All plots received $100 \mathrm{lb} \mathrm{P}_{2} \mathrm{O}_{5} / \mathrm{A}$ in 1955 and $200 \mathrm{lb} \mathrm{P}_{2} \mathrm{O}_{5} / \mathrm{A}$ in 1956. In 1955, treatments No. 2, 3, and 4 received only $50,50+50$, and $100 \mathrm{lb} \mathrm{K} \mathrm{K}_{2} \mathrm{O} / \mathrm{A}$, respectively.

**Mean of four replications from Agronomy Farm, Morgantown.

\section{EXPERIMENT II}

\section{Procedures}

Demonstration trials were established in ten West Virginia counties in 1959. Available $K$ in the soil was determined initially by soil test and the farms were grouped into low, medium, or high. On each farm a 1/10 acre well-drained area was selected with uniform slope, fertility, soil type, and alfalfa stand, with a $\mathrm{pH}$ of 6.5 or higher. Alfalfa had been seeded by the farmer in 1957 or 1958. Four plots $(1 / 40 \mathrm{~A})$ were laid out on each farm. Plot 1 was the check plot. Plot 2 received $500 \mathrm{lb} / \mathrm{A} / \mathrm{yr}$ of $0-20-0$. Plot 3 received $500 \mathrm{lb} / \mathrm{A} / \mathrm{yr}$ of $0-20-20$. Plot 4 received $500 \mathrm{lb} / \mathrm{A} / \mathrm{yr}$ of $0-20-40$. All fertilizer was applied after the first cutting of alfalfa. Alfalfa weevil was controlled by granular heptachlor at the recommended rates, which was prior to its being removed from use. Alfalfa plants were counted in a 3 -sq. $\mathrm{ft}$. area at three locations randomly selected in each plot in 1961 and 1962 and the mean value was calculated.

In the spring of 1963, soil samples from some of the demonstration plots were analyzed for $\mathrm{pH}$, lime requirement, $\mathrm{P}$ and $\mathrm{K}$. First-cutting hay was harvested and yields were caluclated. Percentage of alfalfa in the stand was 
estimated visually and alfalfa yield in T/A was calculated. The data were analyzed statistically using each farm as a replication.

\section{RESULTS}

\section{Persistence}

Initial available soil $\mathrm{K}$ for the demonstration trials in ten West Virginia counties showed 9, 17, and 8 farms in the low, medium, and high available soil $\mathrm{K}$ categories, respectively (Table 3 ). In 1961, density of alfalfa stand and initial level of soil $\mathrm{K}$ for each level of $\mathrm{K}$ applied seemed to be related. However, by 1962 , i.e. during the fourth or fifth year, stand counts were considerably lower on farms where available soil $\mathrm{K}$ was initially low or medium. Stand counts were higher on the farms where the initial available soil $K$ was high. Application of 100 and $200 \mathrm{lb} \mathrm{K} \mathrm{K}_{2} \mathrm{O} / \mathrm{A}$ to the plots that were initially low or medium in avail. able soil $\mathrm{K}$ helped to maintain a greater number of alfalfa plants per plot. By 1962, application of $200 \mathrm{lb} \mathrm{K}_{2} \mathrm{O} / \mathrm{A}$ was even beneficial on the farms initially high in available soil $\mathrm{K}$.

Percentage of alfalfa found in the stands likewise increased (Table 4) as the amount of $\mathrm{K}$ applied increased. $\mathrm{P}$ was also beneficial in maintaining the amount of alfalfa in the stands.

These results demonstrate that alfalfa requires high levels of soil $K$ to be persistent.

Table 3. Density of alfalfa plants in relation to initial amount of available soil $\mathrm{K}$ and applied $\mathrm{K}$ (Experiment II).

Number of alfalfa plants per 3 sq. $\mathrm{ft}$.

\section{1}

Available $K$ in $\quad$ No. of
soil initially
Ib $\mathrm{K}_{2} \mathrm{O} / \mathrm{A}$

$0 \quad 100 \quad 200$
1962

Ib K $\mathrm{O}_{2} \mathrm{~A}$

Demonstration trials in ten West Virginia counties

$\begin{array}{crrrrrrr}\text { Low } & 9 & 10.0 & 11.3 & 13.2 & 8.5 & 10.0 & 11.4 \\ \text { Medium } & 17 & 11.4 & 12.8 & 13.8 & 7.8 & 9.3 & 10.6 \\ \text { High } & 8 & 17.1 & 16.6 & 16.8 & 13.2 & 13.0 & 15.1\end{array}$

\section{Available Soil K}

The amount of available soil $\mathrm{K}$ significantly increased as $\mathrm{K}$ was added from 0 to 100 to $200 \mathrm{lb} \mathrm{K}$ O/A on the 14 West Virginia farms (Table 4).

\section{Yield}

First-cutting hay yield increased significantly (Table 4 ) as the amount of $K$ added increased. Application of $\mathrm{P}$ gave significantly greater yield than the check which received only lime. 
Table 4. Persistence estimates and first-cutting alfalfa hay yields from 14 West Virginia farms in 1963 in relation to available soil $K$ levels and $\mathrm{K}$ fertilization (Experiment II).

\begin{tabular}{|c|c|c|c|}
\hline Treatment & $\begin{array}{c}\text { Available } \\
\text { soil } K^{*} \\
\text { (Ib K } K_{2} \mathrm{O} / \mathrm{A} \text { ) }\end{array}$ & $\begin{array}{c}\text { Alfalfa } \\
(\%)\end{array}$ & $\begin{array}{c}\text { First cutting } \\
\text { hay yield } \\
\text { (dry wt. T/A) }\end{array}$ \\
\hline Lime only & $83^{* *} \mathrm{c}$ & $45 d$ & $0.97 d$ \\
\hline $\begin{array}{l}\text { Lime + } 100 \mathrm{lb} \mathrm{P}_{2} \mathrm{O}_{5} / \mathrm{A} \\
\text { Lime }+100 \mathrm{lb} \mathrm{P}_{2} \mathrm{O}_{5} / \mathrm{A}\end{array}$ & 98 & $58 \mathrm{c}$ & $1.21 \mathrm{c}$ \\
\hline $\begin{aligned} & +100 \mathrm{lb} \mathrm{K} K_{2} \mathrm{O} / \mathrm{A} \\
\text { Lime } & +100 \mathrm{lb} \mathrm{P}_{2} \mathrm{O}_{5} / \mathrm{A} \\
+ & 200 \mathrm{lb} \mathrm{K} K_{2} \mathrm{O} / \mathrm{A}\end{aligned}$ & 149 & $75 b$ & $1.42 b$ \\
\hline
\end{tabular}

\section{EXPERIMENT III}

\section{Procedures}

Vernal alfalfa was established in 1961 at Point Pleasant on a Wheeling sandy loam soil, at Wardensville on a Litz shaly silt loam soil, and in 1962 at Morgantown on a Wharton silt loam soil. Prior to seeding, the areas were limed to a $\mathrm{pH}$ of 6.5 with ground agricultural lime as required by soil test and fertilized with $500 \mathrm{lb} / \mathrm{A}$ of 0-20-20 fertilizer. Each area was subdivided into three blocks with all treatments in each block on separate plots $9^{\prime} \times 15^{\prime}$. In each replication, time of application was the main plot and rates of application were used as sub-plots, both randomly assigned. Soil was tested annually in the early spring and $\mathrm{K}$ fertilizer was added as $\mathrm{KCl}$ (60 per cent $\mathrm{K}_{2} \mathrm{O}$ ) every year to maintain available soil $\mathrm{K}$ at 200,300 , and $400 \mathrm{lb} \mathrm{K} \mathrm{K}_{2} \mathrm{O} / \mathrm{A}$.

Time of application of $\mathrm{K}$ to the plots was as follows:

1. All in early spring

2. All after first cutting

3. All after second cutting

4. All in late fall

5. Split $-1 / 2$ in early spring, $1 / 2$ after second cutting

6. Split $-1 / 2$ after first cutting, $1 / 2$ in late fall

The crop was harvested at early to mid-bloom stage and total plot yield was recorded. A subsample was dried to determine moisture content and used to calculate dry-matter yield on an acre basis. The sample was ground and a $0.5 \mathrm{~g}$ sub sample was dry ashed 6 hours at $475^{\circ} \mathrm{C}$ and suspended in $0.3 \mathrm{~N} \mathrm{HNO}_{3} . \mathrm{K}$ 
and $\mathrm{Mg}$ contents were determined by flame emission on a Beckman DU spectrophotometer using wavelengths of $404.6 \mathrm{m \mu}$ and $383 \mathrm{m \mu}$, respectively. Ca was also determined by flame emission at a wavelength of $422.7 \mathrm{m \mu}$ after addition of $\mathrm{LaCl}_{3}$. Lanthanum was used to suppress interference from other ions. $\mathrm{P}$ content was determined using the molybdivanadophosphoric procedure (29). Percentage of alfalfa on each plot was estimated visually prior to each cutting in 1965. The experiment was terminated in 1966 due to severe weevil damage.

\section{RESULTS}

\section{Yield}

Prior to 1964, yields from the various treatments in this experiment were not significantly different and are not reported. Various treatments at Wardensville yielded no significant differences throughout the duration of the experiment, probably due to the very low rainfall received at that location during these years.

Maintenance of soil $\mathrm{K}$ at the 300 and $400 \mathrm{lb} \mathrm{K}$ O/A level significantly increased both total yield and yield of alfalfa at Pt. Pleasant in 1964 (Figure 1) and in 1965 (Figure 2) and at Morgantown in 1965 (Figure 3). Very little additional yield was obtained at Morgantown in the second and third cuttings probably due to the lower percentage of alfalfa in the stand compared to $\mathrm{Pt}$. Pleasant.

Early spring application of $\mathrm{K}$ produced more total yield at both locations over all years and treatments (Figure 4). When $K$ was applied as a split application at Morgantown, yields were lower compared to all other single application times. The reason for this is not apparent. This is contrary to results of split application of $\mathrm{K}$ on alfalfa by Kresge and Younts (30). Their maximum yield occurred when $K$ was split between early spring and after the first cutting.

As the soil $\mathrm{K}$ level increased at Pt. Pleasant, the optimum time of application changed (Figure 5). At $200 \mathrm{lb} \mathrm{K}_{2} \mathrm{O} / \mathrm{A}$ in the soil, highest yield resulted from the early spring application of $\mathrm{K}$ and late fall yielded least. On the other hand, when the amount of $\mathrm{K}_{2} \mathrm{O}$ was maintained at 300 or $400 \mathrm{lb} / \mathrm{A}$ in the soil, late fall was equal to or better than early spring application. The other application times, i.e. summer application or split treatments, gave lower yields when $K$ was well supplied. The level of $K$ in the soil was of less importance at Morgantown. Early spring application of $\mathrm{K}$ gave the best yield and the late fall and split applications were poorest.

\section{$K$ Removed in the Crop}

The amount of $\mathrm{K}(\mathrm{Ib} / \mathrm{A} / \mathrm{yr})$ removed in the crops increased progressively from the 200 to 300 to $400 \mathrm{lb} / \mathrm{A}$ levels of $\mathrm{K}_{2} \mathrm{O}$ in the soil (Figures 1, 2, and 3). This was related to the amount of alfalfa present. For example, at Pt. Pleasant, where most of the second and third crop was alfalfa (Figure 2), large amounts of $K$ were removed in the crop, but at Morgantown, where the per cent of alfalfa in the crop was not very high, especially for the second and third cuts (Figure 3), the amount of $\mathrm{K}$ removed in the crop was much less. 


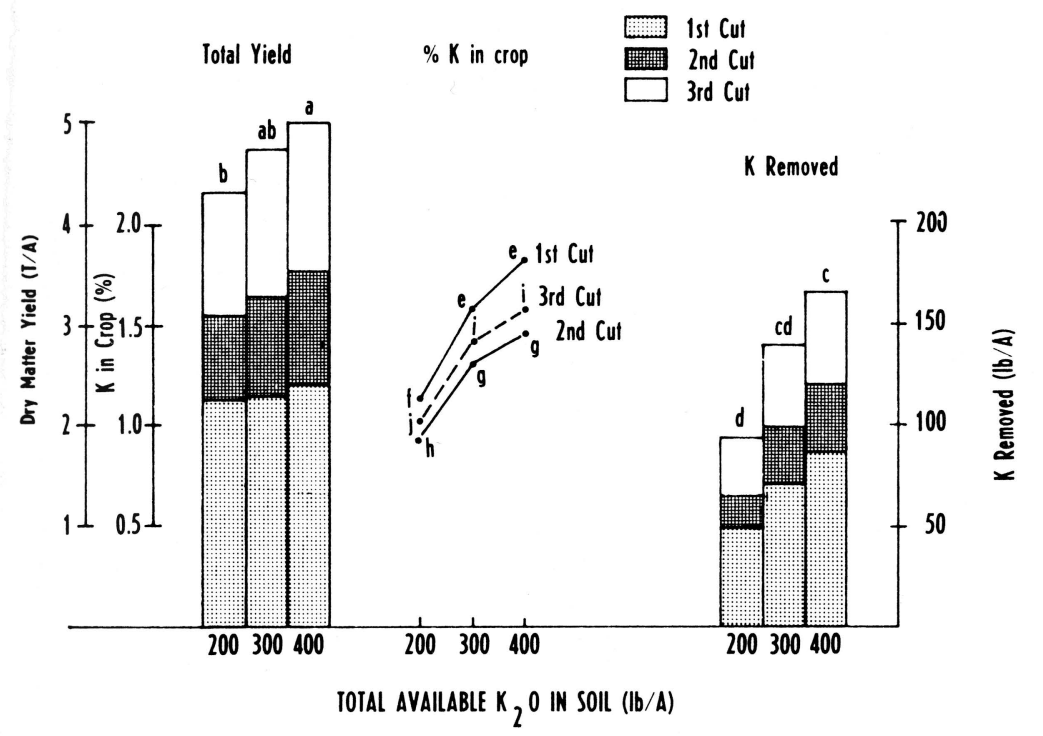

Figure 1. Effect of total available $\mathrm{K}_{2} \mathrm{O} / \mathrm{A}$ in soil on total dry-matter yield, amount of $\mathrm{K}$ removed from soil, and per cent $\mathrm{K}$ in hay at Pt. Pleasant (1964).

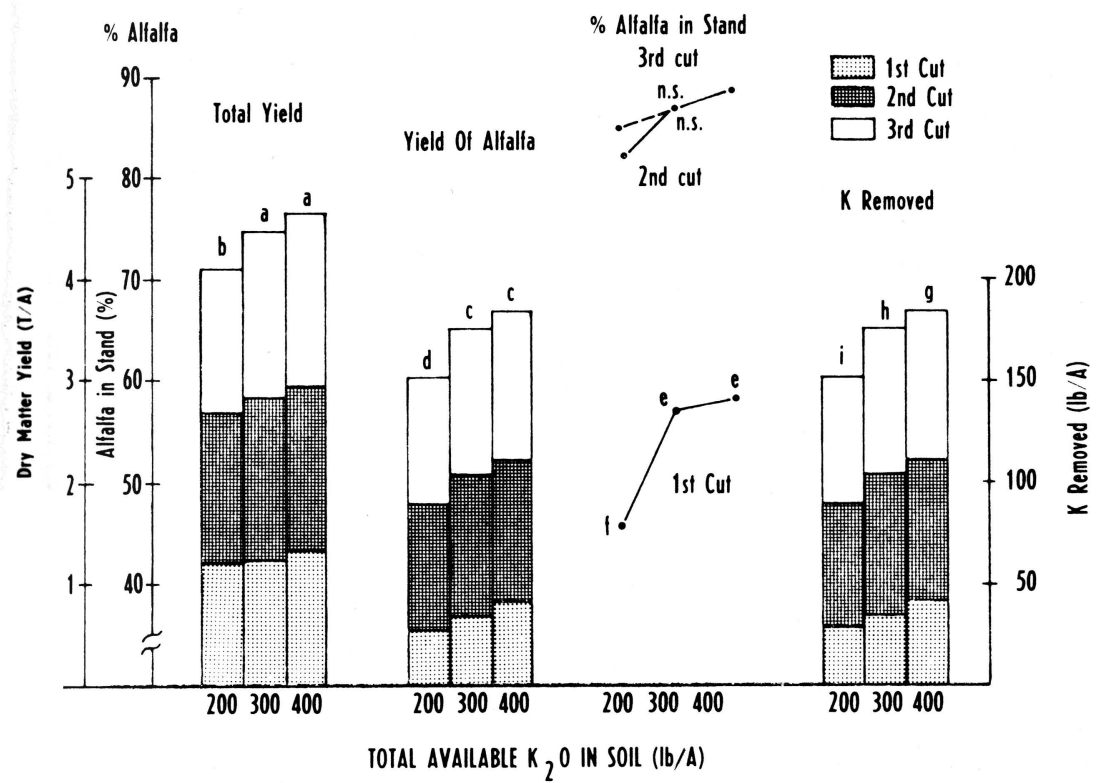

Figure 2. Effect of total available $\mathrm{K}_{2} \mathrm{O} / \mathrm{A}$ in soil on total dry-matter yield, yield of alfalfa, per cent alfalfa in stand, and amount of $\mathrm{K}$ removed from soil at Pt. Pleasant (1965). 


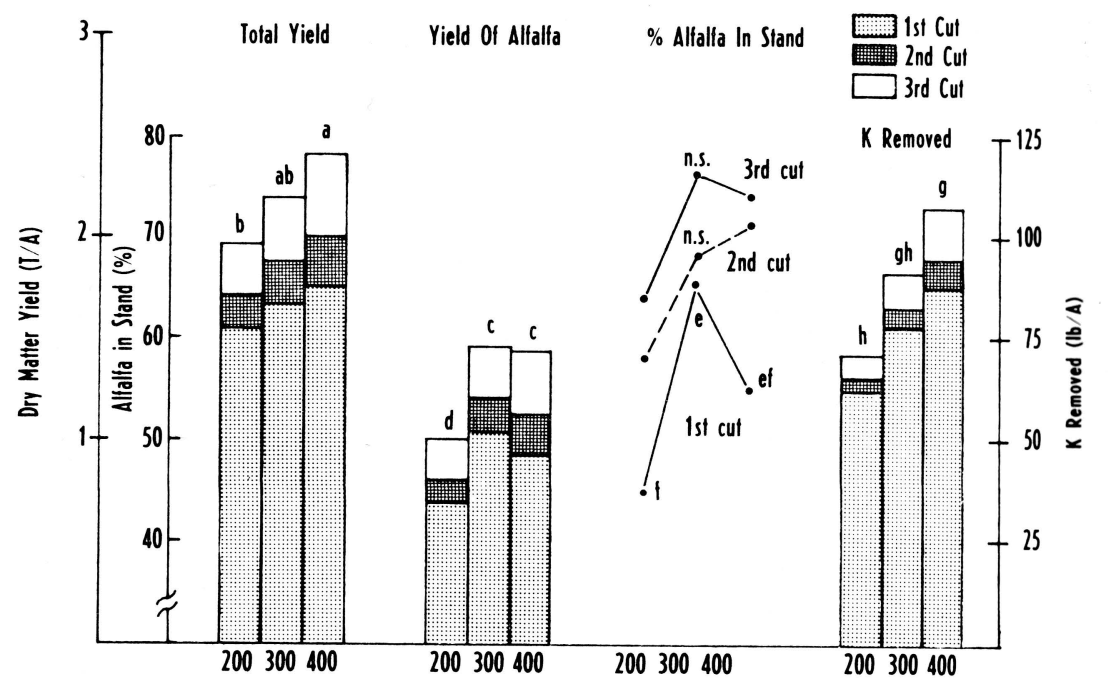

IOTAL AVAllable $K_{2} O$ IN SOIl (Ib/A)

Figure 3. Effect of total available $\mathrm{K}_{2} \mathrm{O} / \mathrm{A}$ in soil on total dry-matter yield, yield of alfalfa, per cent of alfalfa in stand, and amount of $\mathrm{K}$ removed from soil at Morgantown (1965).

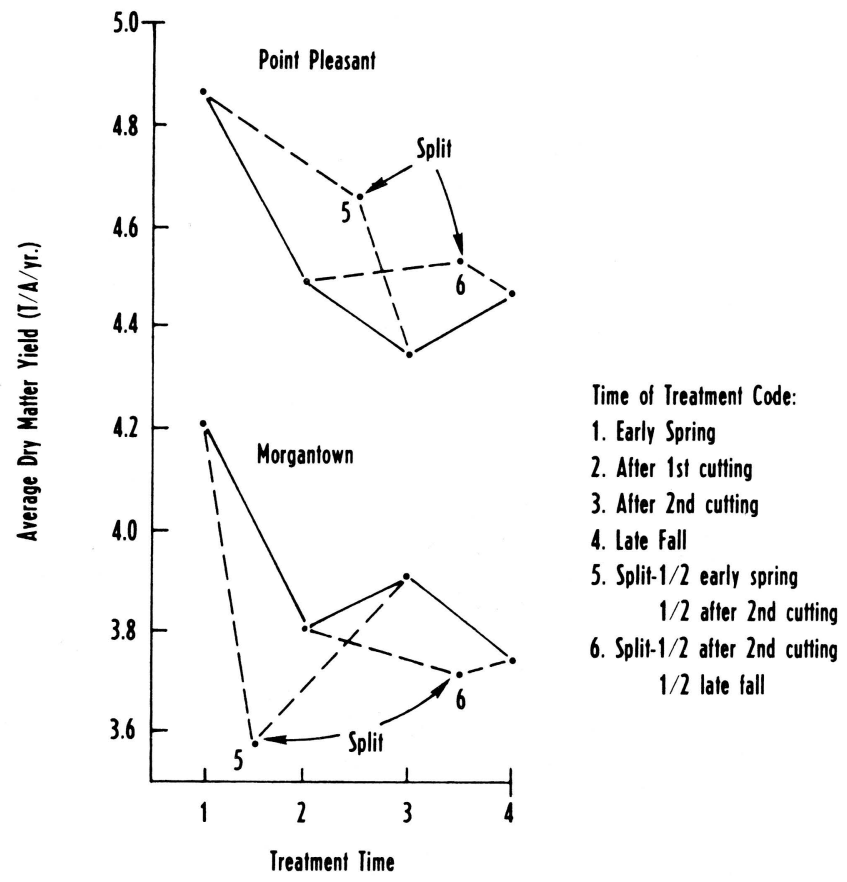

Figure 4. Average dry-matter hay yield in relation to time of application of $K$ at Morgantown and Pt. Pleasant. 

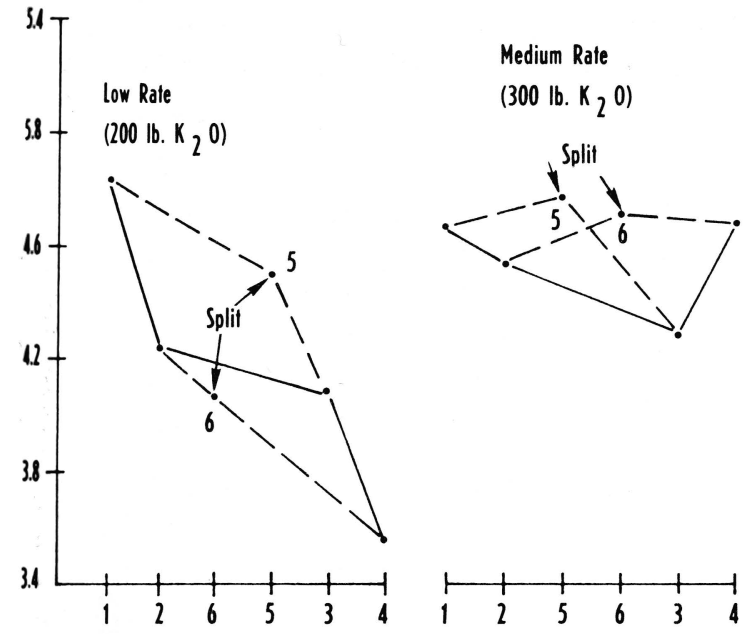

High Rate

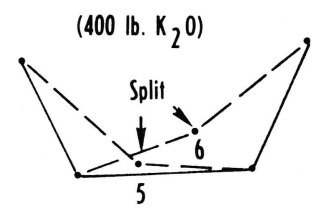

IIME OF K APPLICATION

Figure 5. Total dry-matter yield at each rate of $\mathrm{K}$ application as time of $\mathrm{K}$ application varied at Pt. Pleasant (1965).

The two higher levels of soil $\mathrm{K}$ gave significantly higher percentages of $\mathrm{K}$ in the forage than the lowest level at Pt. Pleasant, for all cuttings in 1964 (Figure 1). However, most of these percentages are below or on the borderline of the 2.0 per cent $\mathrm{K}$ value the most recent source has indicated as being necessary for optimum yield of alfalfa (34).

The amount of $\mathrm{K}$ removed in the forage was well correlated with total dry-matter yield, especially at Pt. Pleasant $(r=0.94)$ and less so at Morgantown $(r=0.77)$ (Figure 6).

The percentage of $K$ in the hay from the first and second cuttings was correlated positively with yield of the first cutting (Table 5), but correlated negatively with the second and third cuttings, i.e. a higher amount of $K$ absorbed by the plants initially, resulted in less yield later in the season. This is probably related to the ability of the indigenous grasses to compete with the alfalfa for K. Furthermore, the percentage of $K$ in the third cutting was not related to yield nor per cent of alfalfa present (Table 5).

\section{Persistence}

The level of available soil $\mathrm{K}$ was influential in determining percentage of alfalfa during the first cutting at Pt. Pleasant in 1965 (Figure 2). The two higher $\mathrm{K}$ levels gave significantly more alfalfa than the lower $\mathrm{K}$ level. There was no significant difference in the percentage of alfalfa in the stand during the second and third cuttings due to level of $K$ in the soil (Figure 2). Similar results were observed at Morgantown in 1965, but all were at a lower level of alfalfa percentage (Figure 3). 
Table 5. Correlation coefficients relating yield and percentage of alfalfa in stand for each cutting with percentages of potassium and phosphorus in each cutting (Experiment III).

$\begin{array}{lllllll} & \% & \% & \% & \% & \% & \% \\ & \text { K1 } & \text { K2 } & \text { K3 } & \text { P1 } & \text { P2 } & \text { P3 } \\ \text { Yield 1 } & .777^{*} & .676^{*} & .281 & .481^{*} & .496^{*} & -.753^{*} \\ \text { \% Alfalfa 1 } & .350 & .410 & .390 & .061 & -.133 & -.203 \\ \text { Yield 2 } & -.592^{*} & -.596^{*} & .059 & -.658^{*} & .568^{*} & .819^{*} \\ \text { \% Alfalfa 2 } & -.164 & -.130 & .189 & -.445^{*} & * .319 & .378 \\ \text { Yield 3 } & -.564^{*} & -.564^{*} & .112 & -.662^{*} & .563^{*} & .801^{*} \\ \text { \% Alfalfa 3 } & -.368 & -.328 & .168 & -.462^{*} & .409 & .533^{*}\end{array}$

Data are mean values for both locations, at all three rates, at all times of $\mathrm{K}$ application.

*Significant at 0.05 level.

K Removed In Crop (b/ $/ \mathrm{A} / \mathrm{yr}$ )

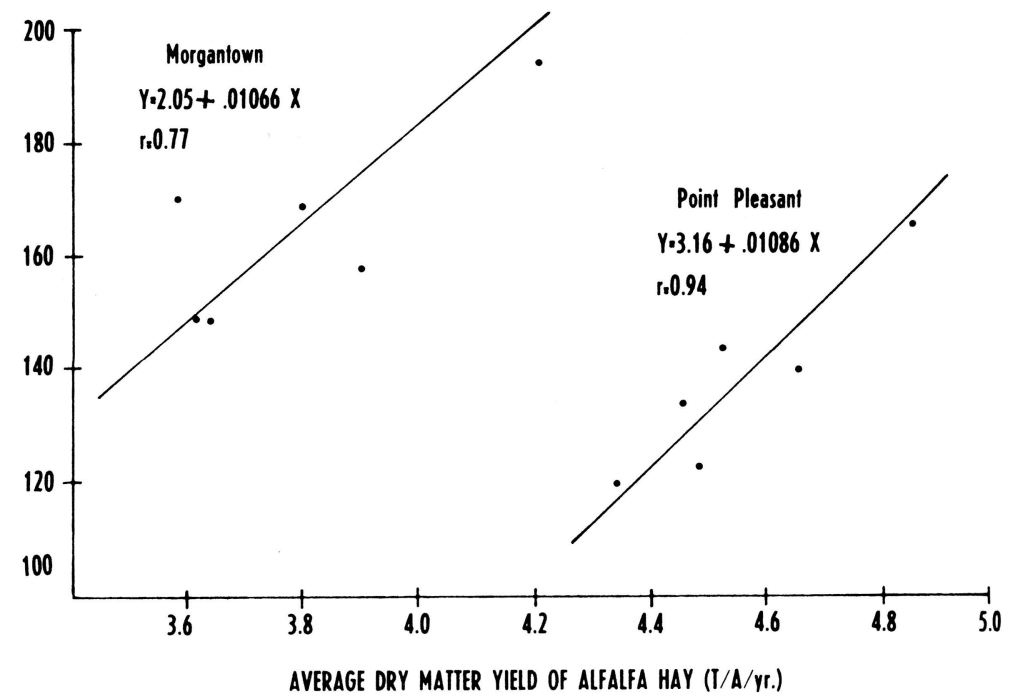

Figure 6. Average dry-matter yield of alfalfa hay in relation to amount of $\mathrm{K}$ removed in the crop at Morgantown and Pt. Pleasant. 
At Pt. Pleasant, there was little reduction in percentage of alfalfa present regardless of time $K$ was applied (Figure 7). There was some benefit by splitting the $\mathrm{K}$ between late fall and after the first cut (Treatment No. 6) on this sandy loam soil. Quite a contrast is seen in the data from Morgantown (Figure 8). Application of $\mathrm{K}$ in the late fall (Treatment No. 4) or splitting the application at two times (Treatments No. 5 and 6 ) resulted in considerably lower percentage of alfalfa in the stand. Apparently this heavier Wharton silty clay loam soil fixed additional $\mathrm{K}$ more easily (26) than the more sandy Wheeling silt loam, especially when $\mathrm{K}$ was applied in the late fall of the year when growth slows down. Highest alfalfa percentage resulted from Treatments 1,2 , or 3 when $K$ was applied during the early spring or during the actively growing period of alfalfa in the summer.

The percentage of alfalfa in the stands was not significantly correlated to per cent $\mathrm{K}$ in the crop (Table 5).

\section{\% Allalla In Stand}
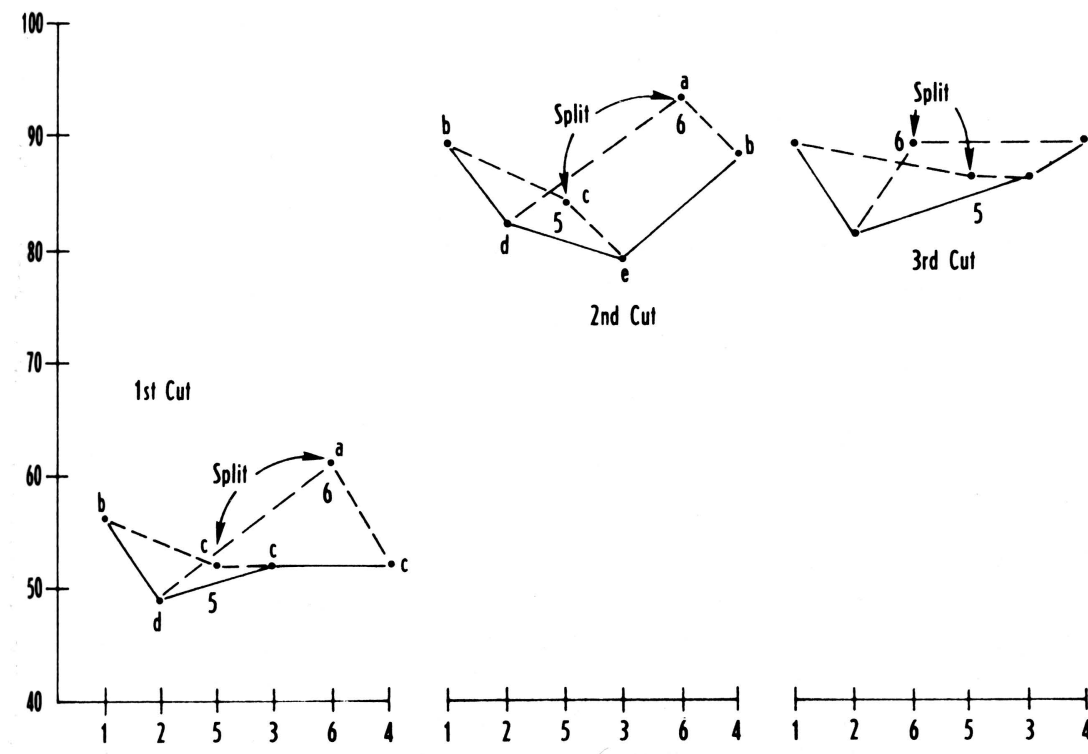

3rd Cut

2nd Cut
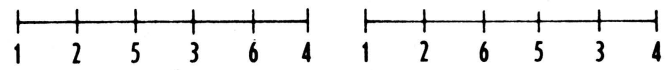

IIME OF K APPLICATION

Figure 7. Percentage of alfalfa in stand in each of three cuttings as time of $\mathrm{K}$ application varied at Pt. Pleasant (1965). 

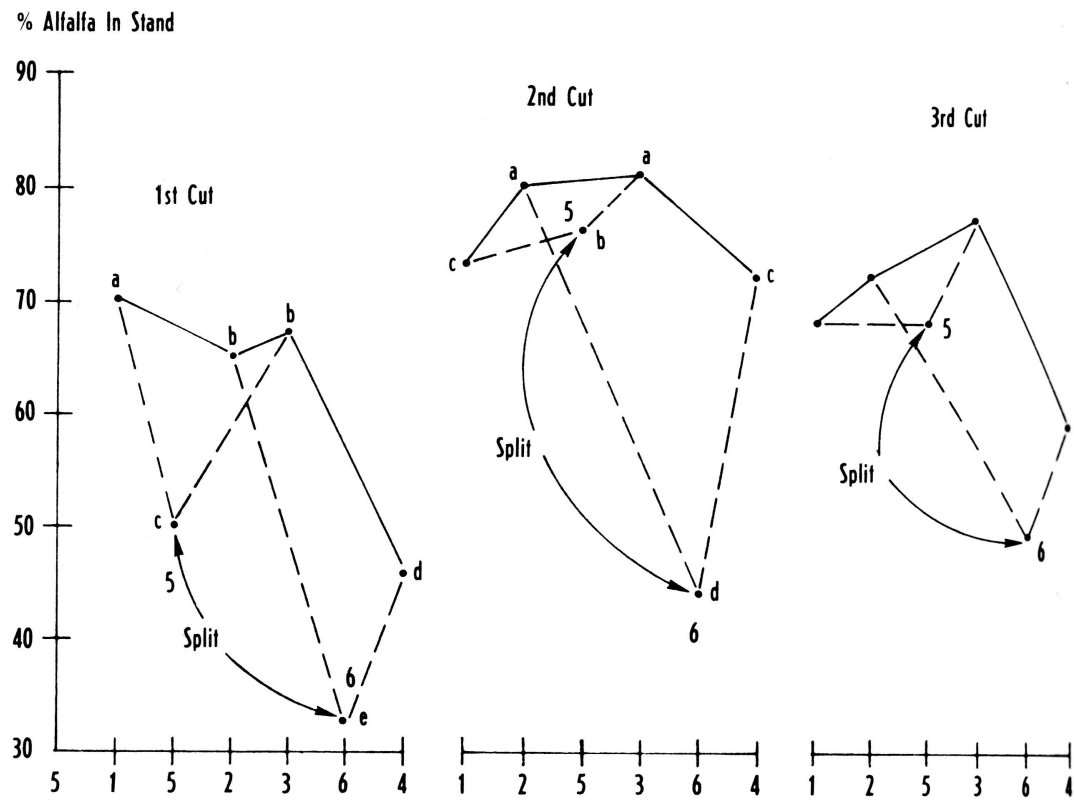

IIME OF K APPLICATION

Figure 8. Percentage of alfalfa in stand in each of three cuttings as time of $K$ application varied at Morgantown (1965).

\section{$\mathrm{P}, \mathrm{Ca}, \mathrm{Mg}$ Found in the Hay Crop}

The percentage of $P$ found in each cutting was positively correlated with yield of that cutting. The large negative correlation coefficients in the per cent $P$ in the first cutting (per cent P1) associated with the yield and per cent alfalfa of the second and third cuttings (Table 5, column 4) indicate that large early uptake of $P$ by the crop may be detrimental to later yield of hay and percentage of alfalfa.

Percentages of $\mathrm{Ca}$ and $\mathrm{Mg}$ in the plant tissue were not consistently correlated with any parameter.

\section{EXPERIMENT IV}

\section{Procedures}

An alfalfa-bromegrass stand was established at the Reedsville Experiment farm on a Rayne silt loam soil in 1967. Analysis of a composite soil sample of the $51^{\prime} \times 108^{\prime}$ site showed a $\mathrm{pH}$ of 5.5, a $3.0 \mathrm{~T} / \mathrm{A}$ lime requirement, $81 \mathrm{lb}$ $\mathrm{P}_{2} \mathrm{O}_{5} / \mathrm{A}$ (medium), and $157 \mathrm{lb} \mathrm{K} \mathrm{K}_{2} \mathrm{O} / \mathrm{A}$ (high). A uniform application of $3 \mathrm{~T} / \mathrm{A}$ of ground agricultural limestone was applied. Eighteen plots $6^{\prime} \times 15^{\prime}$ were laid out with a $3^{\prime}$ border strip separating the three replications. The fertilizer treatments were randomly assigned to the plots within each replication and applied annually in the spring each year as follows: 


\begin{tabular}{|c|c|c|c|}
\hline \multirow{2}{*}{$\begin{array}{c}\text { Treatment } \\
\text { No. }\end{array}$} & \multicolumn{2}{|c|}{$\mathrm{Ib} / \mathrm{A} / \mathrm{yr}$} & \\
\hline & $\mathbf{N}$ & $P_{2} O_{5}$ & $\mathrm{~K}_{2} \mathrm{O}$ \\
\hline A & 0 & 0 & 0 \\
\hline B & 0 & 45 & 45 \\
\hline C & 0 & 90 & 90 Soil Test Recommendation \\
\hline D & 0 & 135 & 135 \\
\hline $\mathrm{E}$ & 0 & 180 & 180 \\
\hline $\mathrm{F}$ & 0 & 90 & 0 \\
\hline G & 0 & 180 & 0 \\
\hline $\mathrm{H}$ & 0 & 0 & 90 \\
\hline I & 0 & 0 & 180 \\
\hline $\mathrm{J}$ & 25 & 90 & 90 \\
\hline $\mathrm{K}$ & 12 & 45 & 45 \\
\hline L & 50 & 180 & 180 \\
\hline M & 0 & 90 & $90+30 \mathrm{lb}$ Borax (10.6 \% boron) \\
\hline $\mathrm{N}$ & 0 & 90 & $90+60 \mathrm{lb}$ Borax \\
\hline 0 & 25 & 90 & $90+30 \mathrm{lb}$ Borax \\
\hline P & 25 & 90 & $90+60 \mathrm{lb}$ Borax \\
\hline 0 & 0 & 180 & $180+30 \mathrm{lb}$ Borax \\
\hline $\mathrm{R}$ & 0 & 180 & $180+60 \mathrm{lb}$ Borax \\
\hline
\end{tabular}

$\mathrm{N}$ was applied as $\mathrm{NH}_{4} \mathrm{NO}_{3} ; \mathrm{P}$ as 20 per cent superphosphate; $\mathrm{K}$ as $\mathrm{KCl}$; and boron as borax. A $3^{\prime}$ strip was harvested from the middle of each plot when the alfalfa was in early bloom stage. Three cuts were made annually and dry-matter production per acre was calculated. Fertilizer was applied at the same rate annually in the early spring, except a soil test for boron after the first year showed very high boron levels so the boron fertilization was discontinued. Soil was tested from the individual plots annually in the spring.

\section{RESULTS}

\section{Yield}

No significant yield differences were observed on the alfalfa-bromegrass hay harvested from the Reedsville farm for the first two years of the experiment. This may be ascribed to the initial high fertility level of the field. By the third year, dry-matter yield differences were observed (Table 6). The general ranking as to yield shows that $K$ was the most beneficial nutrient of the three used (N, $P$, and $\mathrm{K})$ to maintain top yields. Those plots receiving $180 \mathrm{lb} \mathrm{K} \mathrm{K}_{2} \mathrm{O} / \mathrm{A}$ ranked highest in yield, followed by those receiving 135 , then 90,45 , and finally the lowest yields were observed on the plots not receiving $K$; however, those plots receiving more than $90 \mathrm{lb} \mathrm{K} 2 \mathrm{O} / \mathrm{A} / \mathrm{yr}$ were not different statistically. Yields from plots receiving $\mathrm{N}$ and $\mathrm{P}$ were not consistent. Results seem to show no response to $\mathrm{K}$ when applied above $90 \mathrm{lb} \mathrm{K} \mathrm{K}_{2} \mathrm{O} / \mathrm{A} / \mathrm{yr}$ during the three-year period. 
Table 6. Total alfalfa-bromegrass hay yield at Reedsville during the third year (1970) in relation to annual N, $P$, and $K$ fertilization (Experiment IV).

$\begin{array}{rrrl} & \text { Fertilizer applied }(\mathbf{l b} / \mathbf{A} / \mathbf{y r}) & \text { Dry matter yield (T/A) } \\ \mathrm{N} & \mathrm{P}_{2} \mathrm{O}_{5} & \mathrm{~K}_{2} \mathrm{O} & \\ 50 & 180 & 180 & 3.28^{*} \mathrm{a} \\ 0 & 0 & 180 & 3.16 \mathrm{ab} \\ 0 & 180 & 180 & 3.11 \mathrm{ab} \\ 0 & 135 & 135 & 3.11 \mathrm{ab} \\ 0 & 90 & 90 & 3.04 \mathrm{ab} \\ 25 & 90 & 90 & 2.89 \mathrm{abc} \\ 0 & 0 & 90 & 2.88 \mathrm{abc} \\ 0 & 45 & 45 & 2.89 \mathrm{abc} \\ 12 & 45 & 45 & 2.77 \mathrm{bcd} \\ 0 & 90 & 0 & 2.55 \mathrm{cde} \\ 0 & 0 & 0 & 2.38 \mathrm{de} \\ 0 & 180 & 0 & 2.33 \mathrm{e}\end{array}$

* Means significantly different by Duncan's new multiple range test are followed by a different letter.

\section{SUMMARY AND CONCLUSIONS}

\section{Yield}

Experiments reported here under a wide variety of environmental conditions in West Virginia indicate that application of $K$, at least up to 150 and often up to $300 \mathrm{lb} \mathrm{K} \mathrm{O} / \mathrm{A} / \mathrm{yr}$, is beneficial in increasing yields of alfalfa in most cases. No additional yield advantage was realized by maintaining available soil $\mathrm{K}$ above $300 \mathrm{lb} \mathrm{K} \mathrm{K}_{2} \mathrm{O} / \mathrm{A}$. Other nutrients must be adequately supplied to make efficient use of the $K$ applied. Proper management is also necessary for maximum economic yields as indicated by Jung in a recent bulletin (28).

\section{Persistence}

Alfalfa stands were usually maintained by annual application of at least 150 $\mathrm{lb} \mathrm{K} \mathrm{K}_{2} \mathrm{O} / \mathrm{A}$ or maintaining available soil $\mathrm{K}$ at $300 \mathrm{lb} \mathrm{K} \mathrm{K}_{2} \mathrm{O} / \mathrm{A}$. Those fields receiving less than $150 \mathrm{lb} \mathrm{K} \mathrm{K}_{2} \mathrm{O} / \mathrm{A}$ had fewer alfalfa plants surviving. Although of lesser importance than amount of $\mathrm{K}$ applied, as also reported by workers in Maine (9), time of $\mathrm{K}$ application may influence persistence depending on location. Probably soils, climate, and other environmental factors play a role in timing of $K$ application. Early K application, i.e. especially in early spring, or sometimes after the first or second cutting, is usually helpful in maintaining a satisfactory proportion of alfalfa in the stands. Splitting the K application may or may not be beneficial. This agrees with results reported by others in Maryland (30). 


\section{$\mathrm{K}$ in the Hay Crop}

These West Virginia experiments indicate that alfalfa hay usually removes about 35 to $40 \mathrm{lb} \mathrm{K/T}$. Thus, a yield of 4 tons of hay/A removes about $160 \mathrm{lb}$ of actual $\mathrm{K}$ or $192 \mathrm{lb}$ of $\mathrm{K}_{2} \mathrm{O} / \mathrm{A}$. Therefore, in order to supply enough $\mathrm{K}$ for a satisfactory hay yield, a minimum of $200 \mathrm{lb} \mathrm{K}_{2} \mathrm{O} / \mathrm{A}$ should be applied annually to an alfalfa hay crop. Of course, a wise farmer would choose to fertilize somewhat above this level until his fields were registering high in fertilizer nutrients according to soil tests. 


\section{LITERATURE CITED}

1. Anderson, A. J. Available potassium in Preston County soils in relationship to stand maintenance, yield and potassium content of alfalfa. Master of Agriculture Problem Report, W. Va. Univ. 34 pp, 1964.

2. Attoe, O. J. and E. Truog. Correlation of yield and quality of alfalfa and clover hay with levels of available phosphorus and potassium. Soil Sci. Soc. Am. Proc. 14: 249-253, 1949.

3. Bear, F. E., A. L. Prince, and J. L. Malcolm. The potassium supplying powers of 20 New Jersey soils. Soil Sci. 58: 139-144, 1944.

4. Bear, F. E. and A. Wallace. Alfalfa. Its mineral requirements and chemical composition. N.J. Agr. Expt. Sta. Bull. 748, 32 pp., 1950.

5. Blaser, R. E. and N. C. Brady. Nutrient composition in plant associations. Agron. J. 42 $128-135,1950$.

6. Brown, B. A. Effect of fertilizers on maintaining stands of alfalfa. J. Am. Soc. Agron. 20: 109-117, 1928.

7. Brown, B. A., R. I. Munsell, and A. V. King. Potassium and boron fertilization of alfalfa on a few Connecticut soils. Soil Sci. Soc. Am. Proc. 10: 134-140, 1945.

8. Brown, B. A. Fertilizer experiments with alfalfa (1915-1960). Conn. Expt. Sta. Bull. 363, 1961.

9. Brown, C. S. and R. F. Stafford. Simplify alfalfa top-dressing. Better Crops with Plant Food 50: 12-16, 1966.

10. Calder, F. W. and L. B. MacLeod. Effect of cold treatment on alfalfa as influenced by harvesting system and rate of potassium application. Can. J. PI. Sci. 26: 17-26, 1966.

11. Chandler, R. F., Jr., M. Peech, and R. Bradfield. A study of techniques for predicting the potassium and boron requirements of alfalfa: I. The influence of muriate of potash and borax on yield, deficiency symptoms, and potassium content of plant and soil. Soil Sci. Soc. Am. Proc. 10: 141-146, 1945.

12. Chandler, R. F., Jr., M. Peech, and C. W. Chang. The release of exchangeable and non-exchangeable potassium from different soils upon cropping. J. Am. Soc. Agron. 37: 709-721, 1945.

13. Dowdy, R. H. and T. B. Hutcheson, Jr. Effect of exchangeable potassium level and drying on release and fixation of potassium by soils as related to clay mineralogy. Soil Sci. Soc. Am. Proc. 27: 31-34, 1963.

14. Drake, M. Soil chemistry and plant nutrition. In Chemistry of the Soil, Bear, F. E. ed., Reinhold Pub. Corp., New York, N.Y., 515 pp., 1964 (see p. 415).

15. George, J. R., C. L. Rhykerd, and C. H. Noller. Luxury K use ... fact or myth. Better Crops with Plant Food 51 (2): 2-5, 1967.

16. Gervais, P., J. L. Dionne, and W. S. Richardson. Productivity and chemical composition of alfalfa as influenced by varying levels of phosphorus and potassium applications. Can. J. PI. Sci. 42: 1-10, 1962.

17. Gerwig, J. L. and G. H. Ahlgren. The effect of different fertility levels on yield, persistence, and chemical composition of alfalfa. Agron. J. 50: 291-294, 1958.

18. Graber, L. F. and V. G. Sprague. The productivity of alfalfa related to management. J. Am. Soc. Agron. 30: 38-54, 1938.

19. Gray, E., J. S. Rice, and A. J. Hesler. Survival responses of alfalfa varieties to potassium fertilization. Tenn. Farm Home Sci. Progr. Rept. 62: 15-17, 1967.

20. Gross, H. D., E. R. Purvis, and G. H. Ahlgren. The response of alfalfa varieties to different soil fertility levels. Agron. J. 45: 118-120, 1953.

21. Hammer, J. W. Available potassium in the soil in relationship to potassium in the plant, total yield, and stand count of alfalfa. Master of Agriculture Problem Report, W. Va. Univ., 36 pp. 1964. 
22. Hanway, J. J., S. A. Barber, R. H. Bray, A. C. Caldwell, L. E. Engelbert, R. L. Fox, M. Fried, D. Hovland, J. W. Ketcheson, W. M. Laughlin, K. Lawton, R. C. Lipps, R. A. Olson, J. T. Pesek, K. Pretty, F. W. Smith, and E. M. Stickney, North Central Region potassium studies. I. Field studies with alfalfa. Iowa Agr. Expt. Sta. Res. Bull. 494: 163-188, 1961.

23. Hittle, O. N. and J. A. Jackobs. Ten tons alfalfa. Better Crops with Plant Food 50(2): 8-12, 1966.

24. Hopen, H. J., A. C. Caldwell, and R. S. Grant. Potassium fertilization affects yield and K content of alfalfa. Better Crops with Plant Food 49(4): 1-5, 1965.

25. Jackson, M. L. Plant tissue analysis-mineral constituents. In Soil Chemical Analysis. F. E. Bear, ed. Prentice-Hall, Inc., Englewood Cliffs, N. J. 498 pp., 1958.

26. Jencks, E. M. Relationship between exchangeable and boiling nitric acid extractable potassium in seventy-five West Virginia soil series. Agron. J. 60: 636-639, 1968.

27. Jung, G. A. and D. Smith. Influence of soil potassium and phosphorus content on the cold resistance of alfalfa. Agron. J. 51: 585-587, 1959.

28. Jung, G. A., R. L. Reid, and J. A. Balasko. Studies on yield, management, persistence, and nutritive value of alfalfa in West Virginia. W. Va. Agr. Expt. Sta. Bull. 581T, 80 pp., 1969.

29. Kitson, R. E. and M. G. Mellon. Colorimetric determination of phosphorus as molybdivanadophosphoric acid. Ind. Eng. Chem. (Anal. Ed.) 16: 379-383, 1944.

30. Kresge, C. B. and S. E. Younts, Effect of various rates and frequencies of potassium application on yield and chemical composition of alfalfa and alfalfa-orchardgrass. Agron. J. 54: 313-316, 1962.

31. MacLeod, L. B. Effect of nitrogen and potassium fertilization on the yield, regrowth, and carbohydrate content of the storage organs of alfalfa and grasses. Agron. J. 57: 345-350, 1965.

32. Markus, D. K. Chemical composition of lucerne and soil nutrient status as related to fertilization practices. Dissert. Abstr. 25: 5466-5467, 1965.

33. Markus, D. K. and W. R. Battle. Soil and plant responses to long-term fertilization of alfalfa (Medicago sativa L.) Agron. J. 57: 613-616, 1965.

34. Melsted, S. W., H. L. Motto, and T. R. Peck. Critical plant nutirent composition values useful in interpreting plant analysis data. Agron. J. 61: 17-20, 1969.

35. Morris, H. D. and H. F. Perkins. Potassium fertilization of alfalfa on Georgia soils. Ga. Agr. Res. Rept. 7 (1): 4-6, 1966.

36. Moschler, W. W. and S. S. Obenshain. Constant amounts of phosphorus and variable amounts of potassium used by alfalfa. Va. Agr. Expt. Sta. Res. Rept. 40 pp., 1953-1957.

37. Nelson, W. W. and J. M. MacGregor. The effect of time and rate of fertilizer application on the yield, composition, and longevity of alfalfa. Soil Sci. Soc. Am. Proc. 21: 42-46, 1957.

38. Newcomer, J. L. Don't surrender to the weevil. Better Crops with Plant Food 53: 14-15, 1969.

39. Overdahl, C. J. Alfalfa can be grown profitably on coarse soils. Better Crops with Plant Food 52 (4) : 24-27, 1968.

40. Reid, D. J. Potassium fertilization of alfalfa: its effects on yeilds and carbohydrate accumulation. Dissert. Abstr. 25: 3181-3182, 1964.

41. Rich, A. E. and T. E. Odland. The effect of various fertilizers on the botanical composition and yield of grass-legume hay. J. Am. Soc. Agron. 39: 390-394, 1947.

42. Rouse, R. D. and B. R. Bertramson. Potassium availability in several Indiana soils. Its nature and methods of evaluation. Soil Sci. Soc. Am. Proc. 14: 113-123, 1949.

43. Seay, W. A., O. J. Attoe, and E. Truog. Correlation of the potassium content of alfalfa with that available in soils. Soil Sci. Soc. Am. Proc. 14: 245-249, 1949.

44. Smith, D. Alfalfa cutting practices. I. Influence of cutting schedules, soil fertility and insect control on yield and persistence of Vernal and Narragansett alfalfa. Wisc. Agr. Expt. Sta. Res. Rept. 11, 1962. 
45. Stanford, G. Fixation of potassium in soils under moist conditions and on drying in relation to type of clay mineral. Soil Sci. Soc. Am. Proc. 12: 167-171, 1948.

46. Stewart, E. H. and N. J. Volk. Relation between potash in soils and that extracted by plants. Soil Sci. 61: 125-129, 1946.

47. Stivers, R. K. and A. J. Ohlrogge. Influence of phosphorus and potassium fertilization of two soil types on alfalfa yield, stand, and content of these elements. Agron. J. 44: 618-621, 1952.

48. Twamley, B. E. Variety, fertilizer, management interactions in alfalfa. Can. J. PI. Sci. 40: 130-138, 1960.

49. Wang, L. C., O. J. Attoe, and E. Truog. Effect of lime and fertility levels on the chemical composition and winter survival of alfalfa. Agron. J. 45: 381-384, 1953.

50. Whitehead, D. C. and E. C. Jones. Nutrient elements in the herbage of white clover, red clover, lucerne, and sainfoin. J. Sci. Fd. Agr. 20: 584-591, 1969. 